\title{
Diversity of Cropping Systems in Chittagong Region
}

\author{
S M Shahidullah ${ }^{*}$, M Nasim ${ }^{1}$, M K Quais $^{1}$ and A Saha ${ }^{1}$
}

\begin{abstract}
The study was conducted over all 42 upazilas of Chittagong region during 2016 using pre-tested semistructured questionnaire with a view to document the existing cropping patterns, cropping intensity and crop diversity in the region. The most dominant cropping pattern Boro-Fallow-T. Aman occupied about $23 \%$ of net cropped area (NCA) of the region with its distribution over 38 upazilas out 42 . The second largest area, $19 \%$ of NCA, was covered by single T. Aman, which was spread out over 32 upazilas. A total of 93 cropping patterns were identified in the whole region under the present investigation. The highest number of cropping patterns was 28 in Naokhali sadar and the lowest was 4 in Begumganj of the same district. The lowest crop diversity index (CDI) was observed 0.135 in Chatkhil followed by 0.269 in Begumganj. The highest value of CDI was observed in Banshkhali, Chittagong and Noakhali sadar (around 0.95 ). The range of cropping intensity values was recorded $103-283 \%$. The maximum value was for Kamalnagar upazila of Lakshmipur district and minimum for Chatkhil upazila of Noakhali district. As a whole the CDI of Chittagong region was 0.952 and the average cropping intensity at the regional level was $191 \%$.
\end{abstract}

Key words: Crop diversity index, land use, cropping system, soybean, and soil salinity

\section{INTRODUCTION}

The Chittagong region consists of five districts viz Chittagong, CoxBazar, Noakhali, Feni and Lakshmipur. The area belongs to mainly AEZ23, AEZ-18, AEZ-19, AEZ-29 and AEZ-17 which characterized by heavy monsoon rainfall, low soil fertility and exposure to cyclone (FAO, 1988). There are many location-specific constraints for agriculture in this region and dispersed over the whole area. The limitations are severe flash floods, dry-season soil salinity, extremely acid soils, lack of irrigation water, poor drainage, bank erosion, very steep slopes and occurrence of peat soil. Among the socioeconomic problems difficult communication, remoteness of interior areas from urban markets and input supply, and service centres are focal features.

Cropping system is the crop production activity of a farm, which includes all cropping patterns grown on the farm resources, other household enterprises and the physical, biological, technological and socioeconomic factors or environments. A cropping pattern is the yearly sequence, temporal and spatial arrangement of crops in a given land area. It is dependent on physical, historical, social, institutional and economic factors as well as government policies (Agrawal and Kassam, 1976). The cropping pattern and the changes therein depend on a large number of factors like climate, soil type, rainfall, agricultural technology, availability of irrigation facilities and other inputs, marketing and transport facilities and growth of agro-industries (Neena, 1998; Gadge, 2003; Rashid et al., 2005).

The yields of cereal crops are tending to stagnation, even in favourable environments. Moreover, cultivable land area is decreasing day by day in the country. In this context, there is no other alternative but to address less favourable and unfavourable environments. To increase the system productivity of the

${ }^{1}$ Rice Farming Systems Division, BRRI, Gazipur; *Corresponding author's E-mail: shahidullah4567@gmail.com 
total environment it needs to bring diversity in enterprises for better utilization of limited resources. A detailed information package on land situation and cropping systems is a prerequisite for a fruitful development programme. Diversified cropping pattern may be option for the farmers as a coping strategy against risks (Mandal and Bezbaruah, 2013). Typology of different cropping systems is the base for the managers of these systems to intensify production (Shriar, 2000). There is a strong need for judicious and appropriate use of limited resources in case of intervention selection that does not lead to increased mal adaption or inequity in the society over long term. Existing trends of available agricultural lands is most essential requirement for any land use planning related to farming and food security in a sustainable manner. Therefore, an increased understanding of arable land use based on the cropping system is essential for the appropriate intervention in sustainable way. In these context, existing cropping patterns along with their diversity of such complex agricultural region are very crucial for risk minimization and overall productivity improvement. The present study was designed with the following specific objectives to:

- Understand the existing cropping patterns scenario in Chittagong region

- Visualize the existing land use pattern at upazila and regional level

- Determine the crop diversity and cropping intensity at local and regional level.

\section{METHODOLOGY}

Forty-two upazilas of Chittagong, CoxBazar, Feni, Noakhali and Lakshmipur districts under Chittagong agricultural region were the locale of this study. Data were collected using double stage procedure. At initial stage, data were collected through pre-tested semistructured questionnaire from 42 pre-assigned Sub-Assistant Agriculture Officers (SAAO) of each upazila during November 2015 at upazila level. SAAOs were purposively preselected by Agriculture Extension Officers
(AEO), Additional Agriculture Officer (AAO) and Upazila Agriculture Officer (UAO) or altogether. Prior to data collection, the pretested questionnaire was explained along with proper guidelines to the AEOs or UAOs or both and handed over to them at each Deputy Director's office of Department of Agricultural Extension (DAE) during monthly meeting for the sake of accurate data collection. The filled questionnaires were collected by the scientists of RFS Division, checked and analyzed to find the inconsistencies of the supplied data before validation workshop. All the inconsistencies among the information were documented. The collected data along with documented inconsistencies were discussed in district level workshop for necessary correction and validation. Second stage of data collection was day-long data validation workshop at district level. The workshop dates were 20 January for Feni; 17 February for Lakshmipur; 20 March for Noakhali; 7 August for CoxBazar and 8 August 2016 for Chittagong. Four field-workers i.e. one SAPPO and three SAAOs experienced and engaged in crop-based data documentation, all officers from all upazilas viz UAOs, AEOs, AAEOs, DD (DAE), DD (Horticulture), DD of Seed Certification Agency, DTO and ADDs, one representative from Agricultural Training Institute (ATI) and scientists of BRRI Regional Station, Sonagazi, participated in the data validation workshop. The number participants of validation workshop ranged from 51 to 119 in each district. All the participants were divided into three to four groups for data validation. Each group was facilitated by two RFSD scientists to finalize and validate the data and authenticated data were captured. Crop diversity index was calculated by using the following equation described by Kshirsagar et al. (1997).

$$
C D I_{i}=1-\sum_{j=o}^{n}\left(\frac{a_{i j}}{A_{i}}\right)^{2}
$$

Where, $\mathrm{CDI}_{\mathrm{i}}=$ Crop Diversity Index $\mathrm{a}_{\mathrm{ij}}=$ Area planted to the $\mathrm{j}^{\text {th }}$ crop in the $\mathrm{i}^{\text {th }}$ location

$A_{i}=$ Total area planted under all crops 
The index is zero for a land area growing only one crop. It approaches unity as the level of diversity increases. Compilation and processing of collected data were done using Micro Soft Excel programme. Descriptive statistics were used to facilitate the presentation of the findings.

\section{RESULTS AND DISCUSSION}

\section{Land use}

Table 1 presents the status of agricultural land utilization. The net cropped area of the Chittagong region is 655,870 ha. Crops occupied the particular land for round the year were considered under annual crops. The major annual crops reported in the region were pineapple, sugarcane, banana, papaya, betel leaf, ginger and turmeric. The annual crops area in different upazilas ranged from zero to 1,610 ha. The annual crops area accounted only $1.71 \%$ of the net cropped area (NCA) in the region. At a glance, the region occupied $28 \%$ single cropped area (SCA), $49 \%$ double cropped area (DCA), 20\% triple cropped area (TCA). The quadruple cropped area was also seen as a very negligible area $(0.08 \%)$ and is limited in only two upazilas viz Raipur of Lakshmipur and Chakaria of CoxBazar district. The SCA had the major share of NCA in Fatikchhari, Mirsharai, Patiya and Sandwip upazilas of Chittagong district; Teknaf upazila of CoxBazar district; Begumganj, Chatkhil, Kabirhat and Sonaimuri upazilas of Noakhali district followed by corresponding double cropped area (DCA). Most of the upazilas were dominated by DCA. The exceptions were Chandanaish of Chittagong district, Kutubdia of CoxBazar district and Kamalnagar of Lakshmipur district where triple cropped area were dominating (Table 1). The area which could not be defined in the form of definite pattern, was considered as others whose coverage is less than $1 \%$ of the NCA.

\section{Cropping patterns of Chittagong}

In total 93 cropping patterns were observed in Chittagong region of which eight cropping patterns with exclusive rice crop covers about
$57 \%$ of the NCA. There were 19 cropping patterns with exclusive non-rice crop covering only $2.5 \%$ of the NCA. Rest of the NCA i.e. over $40 \%$ area was covered by 66 rice - non rice cropping patterns (Appendix 1).

\section{Rice and non-rice crops at a glance}

Table 2 presents eight cropping patterns where rice is the only crop round the year. It comprised of about $57 \%$ of the NCA in the region. Among them single rice, double rice and triple rice areas represented around 27\%, 28\% and $2 \%$ respectively. It reflected the unparallel dominance of rice in the cropping systems in Chittagong region. In the case of individual pattern Boro-Fallow-T. Aman had the highest coverage $(23 \%)$ and was recorded in 38 upazilas out of 42 . The second dominant pattern single T. Aman area occupied 19\% of NCA, which was reported in 32 upazilas. Single Boro covered 7\% area with its existence in only 12 upazilas.

In the current investigation, 19 cropping patterns were identified free from rice. Out of these 19 patterns, first 12 were arranged in the descending order in Table 3. The rest seven patterns with negligible area coverage are presented in Table 7 where they are arranged with other patterns of different categories. The total area of the 19 patterns was only $2.51 \%$ of NCA. So, it is clear from the study that exclusive rice area is about 23 folds of exclusive non-rice area. Among these 19 patterns, three patterns comprised of year-round vegetables distributed over majority of the upazilas. Year-round vegetable production system was observed about two-thirds of the non-rice cropping area and mainly practiced on or beside the homestead area.

\section{Pulse crops}

Twenty cropping patterns were holding different pulse crops (Table 4). Among them grasspea was covering the largest area whereas pea was in the smallest area. Three cropping patterns of grass pea jointly covered more than $7 \%$ of NCA. Felon (Vigna unguiculata) occupied the second position in pulse crop cultivation in 
Table 1. Land use of different upazilas in Chittagong region (area in hectare), 2014-15.

\begin{tabular}{|c|c|c|c|c|c|c|c|c|c|c|}
\hline & Upazila & $\begin{array}{l}\text { Area of } \\
\text { upazila }\end{array}$ & $\begin{array}{l}\text { Annual } \\
\text { crop }\end{array}$ & SCA & DCA & TCA & QCA & Other & NCA & C.I. (\%) \\
\hline 01 & Anwara & 16413 & 40 & 1520 & 4210 & 2540 & 0 & 130 & 8440 & 212 \\
\hline 03 & Boalkhali & 13753 & 10 & 2600 & 3270 & 200 & 0 & 130 & 6210 & 160 \\
\hline 04 & Chandanaish & 20199 & 410 & 2230 & 3190 & 3910 & 0 & 120 & 9860 & 213 \\
\hline 07 & Lohagara & 25887 & 150 & 2200 & 8170 & 300 & 0 & 130 & 10950 & 181 \\
\hline 08 & Mirsharai & 48800 & 110 & 10800 & 3590 & 8550 & 0 & 110 & 23160 & 190 \\
\hline 09 & Patiya & 31647 & 180 & 6350 & 4470 & 2550 & 0 & 130 & 13680 & 171 \\
\hline 10 & Rngunia & 34775 & 300 & 6100 & 10780 & 1200 & 0 & 120 & 18500 & 172 \\
\hline 14 & Sitakunda & 48400 & 200 & 1350 & 5100 & 3040 & 0 & 110 & 9800 & 215 \\
\hline 15 & Chakaria & 50300 & 370 & 900 & 12270 & 7810 & 50 & 170 & 21570 & 231 \\
\hline 16 & CoxBazar & 19965 & 440 & 550 & 8605 & 210 & 0 & 135 & 9940 & 192 \\
\hline 17 & Kutubdia & 15102 & 0 & 150 & 400 & 2755 & 0 & 95 & 3400 & 279 \\
\hline 18 & Maheskhali & 38850 & 1610 & 1110 & 7510 & 10 & 0 & 120 & 10360 & 174 \\
\hline 19 & Pekua & 13968 & 50 & 0 & 4695 & 3125 & 0 & 180 & 8050 & 239 \\
\hline 20 & Ramu & 39171 & 150 & 940 & 8950 & 315 & 0 & 145 & 10500 & 193 \\
\hline 21 & Teknaf & 34938 & 520 & 8000 & 2630 & 200 & 0 & 120 & 11470 & 127 \\
\hline 28 & Sonagazi & 28500 & 20 & 5600 & 12160 & 2550 & 0 & 190 & 20520 & 185 \\
\hline 29 & Kamalnagar & 31500 & 80 & 0 & 3450 & 18000 & 0 & 150 & 21680 & 283 \\
\hline 30 & Lakshmipur & 48845 & 70 & 2000 & 19450 & 4450 & 0 & 150 & 26120 & 209 \\
\hline 31 & Ramganj & 16932 & 50 & 3950 & 6590 & 590 & 0 & 120 & 11300 & 169 \\
\hline 32 & Ramgati & 37500 & 100 & 150 & 4020 & 19650 & 0 & 280 & 24200 & 281 \\
\hline 33 & Raipur & 26260 & 100 & 300 & 12700 & 2745 & 450 & 305 & 16600 & 220 \\
\hline 34 & Begumganj & 23766 & 20 & 15000 & 1300 & 0 & 0 & 100 & 16420 & 108 \\
\hline 35 & Chatkhil & 13395 & 80 & 7870 & 160 & 40 & 0 & 80 & 8230 & 103 \\
\hline 36 & Companiganj & 32400 & 50 & 8200 & 13835 & 305 & 0 & 110 & 22500 & 165 \\
\hline 37 & Hatiya & 210137 & 40 & 8000 & 25800 & 21500 & 0 & 150 & 55490 & 224 \\
\hline 38 & Kabirhat & 23924 & 30 & 7200 & 4405 & 110 & 0 & 125 & 11870 & 139 \\
\hline 39 & Noakhali & 33621 & 1200 & 7150 & 9750 & 6460 & 0 & 140 & 24700 & 192 \\
\hline 40 & Senbag & 15937 & 80 & 1840 & 7760 & 750 & 0 & 150 & 10580 & 189 \\
\hline 41 & Sonaimuri & 17353 & 20 & 10350 & 70 & 200 & 0 & 130 & 10770 & 104 \\
\hline \multirow[t]{2}{*}{42} & Subarnachar & 57600 & 20 & 11300 & 21670 & 4850 & 0 & 130 & 37970 & 183 \\
\hline & Chittagong regic & & 11230 & 183080 & 321655 & 133720 & 500 & 5685 & 655870 & 191 \\
\hline
\end{tabular}


Table 2. Cropping patterns with exclusive rice in Chittagong region, 2014-15.

\begin{tabular}{llccc}
\hline & Cropping pattern & Area (ha) & \% of NCA & Frequency (no. of upazila) \\
\hline 01 & Boro-Fallow-T. Aman & 150280 & 22.92 & 38 \\
02 & Fallow-Fallow-T. Aman & 125600 & 19.15 & 32 \\
03 & Boro-Fallow-Fallow & 48710 & 7.43 & 12 \\
04 & Fallow-Aus-T. Aman & 27140 & 4.14 & 20 \\
05 & Boro-Aus-T. Aman & 16070 & 2.45 & 18 \\
06 & Boro-B.Aman & 2850 & 0.43 & 3 \\
07 & Fallow-Aus-Fallow & 1000 & 0.15 & 1 \\
08 & Boro-Aus-Fallow & 900 & 0.14 & 5 \\
\hline
\end{tabular}

Table 3. Cropping patterns with exclusive non-rice in Chittagong region, 2014-15.

\begin{tabular}{|c|c|c|c|c|}
\hline & Cropping pattern & Area (ha) & $\%$ of NCA & Frequency (no. of upazila) \\
\hline 01 & Vegetab-Vegetab-Vegetab & 5235 & 0.80 & 15 \\
\hline 02 & Vegetab-Fallow-Fallow & 3920 & 0.60 & 11 \\
\hline 03 & Vegetab-Vegetab-Fallow & 2560 & 0.39 & 10 \\
\hline 04 & Soybean-Fallow-Fallow & 2000 & 0.30 & 1 \\
\hline 05 & Tobacco-Sesbania & 600 & 0.09 & 1 \\
\hline 06 & Groundnut-Fallow-Fallow & 440 & 0.07 & 3 \\
\hline 07 & Chilli-Fallow-Fallow & 300 & 0.05 & 3 \\
\hline 08 & S.Potato-Fallow-Fallow & 300 & 0.05 & 3 \\
\hline 09 & Felon-Fallow-Fallow & 260 & 0.04 & 2 \\
\hline 10 & Coriander-Fallow-Fallow & 250 & 0.04 & 8 \\
\hline 11 & W.Melon-Fallow-Fallow & 195 & 0.03 & 3 \\
\hline 12 & Chilli-Vegetab-Fallow & 130 & 0.02 & 5 \\
\hline \multirow[t]{2}{*}{$13-19$} & Other seven patterns (in Table 7) & 280 & 0.04 & - \\
\hline & Total & 16470 & 2.51 & \\
\hline
\end{tabular}

Table 4. Area for pulse crops in cropping systems in Chittagong region, 2014-15.

\begin{tabular}{rlccc}
\hline & Cropping pattern & Area (ha) & \% of NCA & Frequency (no. of upazila) \\
\hline 01 & Grasspea-Fallow-T. Aman & 30640 & 4.67 & 13 \\
02 & Grasspea-Aus-T. Aman & 16740 & 2.55 & 11 \\
03 & Felon-Fallow-T. Aman & 14630 & 2.23 & 28 \\
04 & Mungbean-Aus-T. Aman & 7040 & 1.07 & 9 \\
05 & Felon-Aus-T. Aman & 5045 & 0.77 & 11 \\
06 & Mungbean-Fallow-T. Aman & 4335 & 0.66 & 15 \\
07 & Lentil-Fallow-T. Aman & 2440 & 0.37 & 5 \\
08 & Pea-Fallow-T. Aman & 730 & 0.11 & 4 \\
09 & Lentil-Aus-T. Aman & 500 & 0.08 & 2 \\
10 & Felon-Aus-Fallow & 420 & 0.06 & 2 \\
11 & Felon-Fallow-Fallow & 260 & 0.04 & 1 \\
12 & Grasspea-B.Aman & 250 & 0.04 & - \\
$13-20$ & Other eight patterns (in Table 7) & 290 & 0.04 & 2.71 \\
\hline
\end{tabular}


Chittagong region. There were four cropping patterns for felon where two were dominants viz Felon-Fallow-T. Aman and Felon-Aus-T. Aman. These felon containing cropping patterns in-together occupy over 3\% of NCA. In the documentation of pulse cropping felon reported its widest spreading in the region. One pattern was available in 28 upazilas and the other existed in 11 upazilas. Finally the aggregate area of the pulse cropping systems stood for approximately $13 \%$ of the NCA in Chittagong region. Relatively stress-tolerant pulse crops like grasspea, felon, cowpea are easy to cultivate during pre-monsoon in the dry land (FAO, 1988).

\section{Oil-seed crops}

Soybean is the most important one among the oilseed crops in Chittagong region. There were 17 cropping patterns for oil-seed crops among which six patterns had been led by soybean alone (Table 5). The total share of oil-seed cropping patterns was about $14 \%$ of NCA whereas soybean absolutely occupies over 10\%. The second prevailing groundnut covered over $2 \%$. However, the dominance of oil-seed crops and its spreading over the region are not running in the same direction. The soybean, with its highest coverage, is available only in six upazilas out of 42. In Bangladesh there is a vast market of soybean seeds for feed industries. Loam and sandy soils of the coastal area were found very suitable for soybean cultivation (FAO, 1988). Area under soybean cultivation in Chittagong region is equivalent to the $90 \%$ of the national acreage for the crop.

\section{Vegetables and spices crops}

Table 6 presents 35 cropping patterns arranged in descending order according to area coverage. Potato and other vegetables of Rabi, Kharif-I and Kharif-II; spices viz chilli, onion, garlic and coriander are included in this list. The most contributing cropping pattern was VegetabFallow-T. Aman covering about 3\% of NCA, which was distributed over 28 upazilas. The second one is Chilli-Fallow-T. Aman covering over $1 \%$ of NCA and it is the most available pattern recorded in 30 upazilas out of 42 . The aggregate area allotted for vegetables and spices crops was 76,590 hectares that was equivalent to $11.69 \%$ of NCA in the region. The main spices crop is chilli grown in an area of 13,120 ha (2\% of NCA). Probably two friendly factors encourages the famers for growing chilli viz favourable environments of charland and easy availability of women labour for harvesting and post harvest management of the crop (FAO, 1988).

\section{Sporadic and distinct cropping patterns}

There were some cropping patterns extremely location-specific, however, with a large area coverage. These were Soybean-B. Aman, Soybean-Fallow-Fallow and Soybean-Jute-T. Aman (Table 5). The Soybean-B. Aman is grown on 4,300 hectares in Raipur upazila of Lakshmipur district. Single soybean crop is limited to only Lakshmipur sadar upazila (2,000 ha). Soybean-Jute-T. Aman is available in Kamalnagar (6,400 ha) and Ramgati $(13,000$ ha) of Lakshmipur district.

\section{Rare cropping patterns}

In the present investigation, 24 cropping patterns have been identified as rare cropping patterns with a negligible area coverage with seldom existence (Table 7). These are location specific system and are limited in one or two or in some cases three upazilas of the region. Total area coverage of the 24 patterns is far less than $1 \%$ of NCA. Among them, the highest area was allotted for Sweet potato-B. Aman and Wheat-Fallow-T. Aman (100 ha for each). The smallest area was recorded for four cropping patterns whose coverage was five hectares for each (Table 7).

\section{Most dominant cropping pattern}

Boro-Fallow-T. Aman was the most dominant cropping pattern in Chittagong region. It covers $22.92 \%$ of NCA in the region and is available in 38 upazilas out of 42 (Table 8). The highest area under this cropping was recorded 13,700 hectares in Lakshmipur sadar upazila represents $9.12 \%$ of the total Boro-Fallow-T. Aman area of the region. In consideration of individual upazila CoxBazar sadar has stood 
Table 5. Cropping patterns with oil-seed crops in Chittagong region, 2014-15.

\begin{tabular}{|c|c|c|c|c|}
\hline & Cropping pattern & Area (ha) & $\%$ of NCA & Frequency (no. of upazila) \\
\hline 01 & Soybean-Aus-T. Aman & 22600 & 3.45 & 5 \\
\hline 02 & Soybean-Jute-T. Aman & 19400 & 2.96 & 2 \\
\hline 03 & Soybean-Fallow-T. Aman & 18670 & 2.85 & 6 \\
\hline 04 & Groundnut-Fallow-T. Aman & 8630 & 1.32 & 16 \\
\hline 05 & Groundnut- Aus-T. Aman & 8350 & 1.27 & 6 \\
\hline 06 & Soybean-B.Aman & 4300 & 0.66 & 1 \\
\hline 07 & Mustard-Fallow-T. Aman & 2370 & 0.36 & 15 \\
\hline 08 & Soybean-Fallow-Fallow & 2000 & 0.31 & 1 \\
\hline 09 & Soybean-Aus-Fallow & 700 & 0.11 & 1 \\
\hline 10 & Vegetab-Groundnut-T. Aman & 700 & 0.11 & 1 \\
\hline 11 & Mustard-Boro-T. Aman & 660 & 0.10 & 9 \\
\hline 12 & Groundnut-Fallow-Fallow & 440 & 0.07 & 3 \\
\hline 13 & Mustard-Aus-T. Aman & 345 & 0.05 & 5 \\
\hline 14 & Mustard-Boro-Aus-T. Aman & 270 & 0.04 & 3 \\
\hline 15 & Potato-Sesame-T. Aman & 200 & 0.03 & 1 \\
\hline 16 & Sesame-Fallow-T. Aman & 175 & 0.03 & 5 \\
\hline \multirow[t]{2}{*}{17} & Fallow-Sesame-T. Aman & 10 & 0.00 & 2 \\
\hline & Total oil-seed crops & 89820 & 13.72 & \\
\hline
\end{tabular}

Table 6. Cropping patterns with vegetables and spices crops in Chittagong region, 2014-15.

\begin{tabular}{|c|c|c|c|c|}
\hline & Cropping pattern & Area (ha) & $\%$ of NCA & Frequency (no. of upazila) \\
\hline 01 & Vegetab-Fallow-T. Aman & 17715 & 2.70 & 28 \\
\hline 02 & Chilli-Fallow-T. Aman & 9450 & 1.44 & 30 \\
\hline 03 & Vegetab-Vegetab-T. Aman & 8505 & 1.30 & 18 \\
\hline 04 & Vegetab-Boro-T. Aman & 8150 & 1.24 & 5 \\
\hline 05 & Vegetab-Vegetab-Vegetab & 5235 & 0.80 & 15 \\
\hline 06 & Potato-Fallow-T. Aman & 4555 & 0.69 & 22 \\
\hline 07 & Vegetab-Fallow-Fallow & 3920 & 0.60 & 11 \\
\hline 08 & Vegetab-Aus-Fallow & 2900 & 0.44 & 7 \\
\hline 09 & Vegetab-Vegetab-Fallow & 2560 & 0.39 & 10 \\
\hline 10 & Chilli-Aus-T. Aman & 2450 & 0.37 & 6 \\
\hline 11 & Boro-Vegetab-T. Aman & 1900 & 0.29 & 3 \\
\hline 12 & Vegetab-Boro-Fallow & 1800 & 0.27 & 2 \\
\hline 13 & Potato-Boro-T. Aman & 1650 & 0.25 & 6 \\
\hline 14 & Fallow-Vegetab-T. Aman & 1480 & 0.23 & 8 \\
\hline 15 & Chilli-Aus-Fallow & 770 & 0.12 & 3 \\
\hline 16 & Vegetab-Groundnut-T. Aman & 700 & 0.11 & 1 \\
\hline 17 & Garlic-Fallow-T. Aman & 535 & 0.08 & 10 \\
\hline 18 & Coriander-Fallow-T. Aman & 475 & 0.07 & 13 \\
\hline 19 & Chilli-Fallow-Fallow & 300 & 0.05 & 3 \\
\hline 20 & Coriander-Fallow-Fallow & 250 & 0.04 & 8 \\
\hline 21 & Vegetab-Boro-Aus-T. Aman & 250 & 0.04 & 1 \\
\hline 22 & Onion-Fallow-T. Aman & 245 & 0.04 & 10 \\
\hline 23 & Potato-Sesame-T. Aman & 200 & 0.03 & 1 \\
\hline 24 & Potato-Aus-T. Aman & 165 & 0.03 & 4 \\
\hline 25 & Chilli-Vegetab-Fallow & 130 & 0.02 & 5 \\
\hline \multirow[t]{2}{*}{$26-35$} & Other 10 patterns (in Table 7) & 300 & 0.05 & - \\
\hline & Total for vegetables and spices & 76590 & 11.69 & \\
\hline
\end{tabular}


Table 7. Rare cropping patterns covering non-significant area in Chittagong region, 2014-15.

\begin{tabular}{|c|c|c|c|c|c|}
\hline & Cropping pattern & Area (ha) & $\%$ of NCA & Freq. & Upazila \\
\hline 01 & S.Potato-B.Aman & 100 & 0.02 & 1 & Lakshmipur \\
\hline 02 & Wheat-Fallow-T. Aman & 100 & 0.02 & 3 & Chhagalnaiya+Parshuram+Companiganj \\
\hline 03 & Fallow-Fallow-Blackgram & 80 & 0.01 & 3 & Anwara+Chhagalnaiya+Noakhali sadar \\
\hline 04 & Boro-Sesbania-T. Aman & 70 & 0.01 & 1 & Raipur \\
\hline 05 & Coriander-Vegetab-Fallow & 70 & 0.01 & 3 & Sitakunda+Ramgati+Maheskhali \\
\hline 06 & Lentil-Vegetab-T. Aman & 60 & 0.01 & 1 & Parshuram \\
\hline 07 & Blackgram-Aus-T. Aman & 60 & 0.01 & 2 & Rauzan+ Sitakunda \\
\hline 08 & Muskmelon-Fallow-Fallow & 55 & 0.01 & 2 & Banshkhali+ Ramu \\
\hline 09 & Fallow-B.Aman & 50 & 0.01 & 1 & Kabirhat \\
\hline 10 & Vegetab-Fallow-Blackgram & 50 & 0.01 & 2 & Fulgazi+ Parshuram \\
\hline 11 & Onion-Aus-T. Aman & 45 & 0.01 & 3 & Sandwip+Sitakunda+Ramgati \\
\hline 12 & W.Melon-Aus-T. Aman & 35 & 0.01 & 2 & Sandwip+ Kutubdia \\
\hline 13 & Chilli-Vegetab-T. Aman & 20 & 0.00 & 1 & Mirsharai \\
\hline 14 & Garlic-Aus-T. Aman & 20 & 0.00 & 1 & Ramgati \\
\hline 15 & Mungbean-Aus-Fallow & 20 & 0.00 & 1 & Lohagara \\
\hline 16 & Garlic-Vegetab-Vegetab & 15 & 0.00 & 2 & Maheshkhali+Ramu \\
\hline 17 & Boro-Vegetab(Float/Norm) & 10 & 0.00 & 1 & Kutubdia \\
\hline 18 & Chickpea-Fallow-T. Aman & 10 & 0.00 & 1 & Rangunia \\
\hline 19 & Maize-Maize-T. Aman & 10 & 0.00 & 1 & Chakaria \\
\hline 20 & Fallow-Sesame-T. Aman & 10 & 0.00 & 2 & Companiganj+ Kabirhat \\
\hline 21 & Blackgram-B.Aman & 5 & 0.00 & 1 & Kabirhat \\
\hline 22 & Chickpea-Aus-T. Aman & 5 & 0.00 & 1 & Companiganj \\
\hline 23 & Garlic-Jute-Fallow & 5 & 0.00 & 1 & Sandwip \\
\hline \multirow[t]{2}{*}{24} & Onion-Vegtab-Vegetab & 5 & 0.00 & 1 & Maheshkhali \\
\hline & Total & 910 & 0.14 & & \\
\hline
\end{tabular}

for the sixth position in area coverage, however, it has allocated the highest share i.e. $68 \%$ of its NCA for this pattern alone. Chatkhil, Sitakunda and Sonaimuri upazila had a negligible area coverage for this pattern. In some portion of the double rice area some short duration Rabi crops can be grown before Boro transplanting if appropriate varieties and other related technologies are made available (FAO, 1988). In the country-wide compilation of data it was observed that Boro-F-T. Aman was the most dominant cropping pattern in Bangladesh covering 2.31 million ha $(27 \%$ of NCA in the country) with its distribution in 426 upazilas of 63 districts (Nasim et al., 2017).

\section{Second dominant cropping pattern}

The second dominant cropping pattern in Chittagong region was Fallow-Fallow-T. Aman. It belongs to $19.15 \%$ of NCA of the region and spread over 32 upazilas (Table 9). Fatikchhari and Sandwip upazila of Chittagong district hold the highest are $(12,000$ ha for each) under this single T. Aman cropping. These two upazilas jointly contribute 19\% share of single T. Aman cropping area in the region. Teknaf stands in the sixth position, however, this upazila of CoxBazar district has allocated the biggest share i.e. about $70 \%$ surface of its NCA. Soil salinity is a constraint for the cultivation of Boro rice and Rabi crops in Sandwip, Subarnachar, Hatiya and other saline-prone area. A large area of this pattern is distributed on the valley where irrigation water is not sufficiently available in winter season. All these are the limiting factors for the crop intensification (FAO, 1988). Some stress-tolerant Rabi crops like grasspea, felon, cowpea, sesame etc may undergo for trial to intensify the land-use of the aforesaid system. In the country-wide compilation of data it was observed that the single T. Aman was the $3^{\text {rd }}$ dominant cropping pattern in Bangladesh covering 5.09 lac ha ( $6 \%$ of NCA in the country) with its distribution in 162 upazilas of 36 districts (Nasim et al., 2017). 
Table 8. Distribution of the most dominant Boro-Fallow-T. Aman cropping pattern in Chittagong region, $2014-15$.

\begin{tabular}{|c|c|c|c|c|}
\hline & Upazila & Area (ha) & $\%$ of upazila NCA & $\%$ of the pattern in region \\
\hline 01 & Lakshmipur & 13700 & 52.45 & 9.12 \\
\hline 02 & Chakaria & 10000 & 46.36 & 6.65 \\
\hline 03 & Feni & 9500 & 56.55 & 6.32 \\
\hline 04 & Rngunia & 9100 & 49.19 & 6.06 \\
\hline 05 & Maheskhali & 7000 & 67.57 & 4.66 \\
\hline 06 & Senbag & 7000 & 66.16 & 4.66 \\
\hline 07 & CoxBazar & 6800 & 68.41 & 4.52 \\
\hline 08 & Ramu & 6700 & 63.81 & 4.46 \\
\hline 09 & Fatikchhari & 6500 & 29.47 & 4.33 \\
\hline 10 & Ukhia & 6200 & 61.45 & 4.13 \\
\hline 11 & Chhagalnaiya & 5700 & 53.93 & 3.79 \\
\hline 12 & Rauzan & 5300 & 42.71 & 3.53 \\
\hline 13 & Dagonbhuiyan & 5100 & 49.76 & 3.39 \\
\hline 14 & Satkania & 5000 & 39.31 & 3.33 \\
\hline 15 & Raipur & 4800 & 28.88 & 3.19 \\
\hline 16 & Hathazari & 4600 & 44.57 & 3.06 \\
\hline 17 & Pekua & 4500 & 57.54 & 2.99 \\
\hline 18 & Fulgazi & 4300 & 60.31 & 2.86 \\
\hline 19 & Parshuram & 3600 & 54.05 & 2.40 \\
\hline 20 & Anwara & 3300 & 39.10 & 2.20 \\
\hline 21 & Lohagara & 3300 & 30.14 & 2.20 \\
\hline 22 & Banshkhali & 3000 & 16.87 & 2.00 \\
\hline 23 & Patiya & 2600 & 19.01 & 1.73 \\
\hline 24 & Subarnachar & 2000 & 5.27 & 1.33 \\
\hline 25 & Boalkhali & 1600 & 25.76 & 1.06 \\
\hline 26 & Ramganj & 1500 & 13.27 & 1.00 \\
\hline 27 & Mirsharai & 1400 & 6.04 & 0.93 \\
\hline 28 & Teknaf & 1200 & 10.46 & 0.80 \\
\hline 29 & Kabirhat & 1200 & 10.11 & 0.80 \\
\hline 30 & Companiganj & 1100 & 4.88 & 0.73 \\
\hline 31 & Chandanaish & 700 & 7.10 & 0.47 \\
\hline 32 & Begumganj & 700 & 4.26 & 0.47 \\
\hline 33 & Sonagazi & 600 & 2.92 & 0.40 \\
\hline 34 & Noakhali & 400 & 1.62 & 0.27 \\
\hline 35 & Kamalnagar & 200 & 0.92 & 0.13 \\
\hline 36 & Sonaimuri & 50 & 0.46 & 0.03 \\
\hline 37 & Sitakunda & 20 & 0.21 & 0.01 \\
\hline \multirow[t]{2}{*}{38} & Chatkhil & 10 & 0.12 & 0.00 \\
\hline & Chittagong region & 150280 & 22.92 & 100.00 \\
\hline
\end{tabular}

\section{Third dominant cropping pattern}

Single Boro cropping pattern holds the third largest area coverage 48,710 hectares in Chittagong region. This area is an equivalent to $7.43 \%$ of NCA in the region. This pattern Boro-Fallow-Fallow is distributed over only 12 upazilas. Begumganj has an area of 15,000 ha for single Boro which stands for $30.79 \%$ of the total are under this pattern in the region (Table 10). Chatkhil ranks in third position for single Boro area coverage, however, this upazila has allotted the biggest share $(94.78 \%)$ of its NCA. Diversified cropping pattern may be resort for the farmer as a coping strategy with flood related risk (Mandal and Bezbaruah, 2013) but scope of diversification is limited due to environmental and climatic condition (FAO, 1988). 
Table 9. Distribution of the $2^{\text {nd }}$ dominant F-F-T. Aman cropping pattern in Chittagong region, 2014-15.

\begin{tabular}{|c|c|c|c|c|}
\hline & Upazila & Area (ha) & $\%$ of upazila NCA & $\%$ of the pattern in region \\
\hline 01 & Fatikchhari & 12000 & 54.40 & 9.55 \\
\hline 02 & Sandwip & 12000 & 49.50 & 9.55 \\
\hline 03 & Subarnachar & 11300 & 29.76 & 9.00 \\
\hline 04 & Mirsharai & 10800 & 46.63 & 8.60 \\
\hline 05 & Companiganj & 8200 & 36.37 & 6.53 \\
\hline 06 & Teknaf & 8000 & 69.75 & 6.37 \\
\hline 07 & Hatiya & 8000 & 14.42 & 6.37 \\
\hline 08 & Patiya & 6200 & 45.32 & 4.94 \\
\hline 09 & Rangunia & 6100 & 32.97 & 4.86 \\
\hline 10 & Sonagazi & 5600 & 27.29 & 4.46 \\
\hline 11 & Rauzan & 4000 & 32.23 & 3.18 \\
\hline 12 & Kabirhat & 3500 & 29.49 & 2.79 \\
\hline 13 & Hathazari & 3100 & 30.04 & 2.47 \\
\hline 14 & Dagonbhuiyan & 3000 & 29.27 & 2.39 \\
\hline 15 & Boalkhali & 2600 & 41.87 & 2.07 \\
\hline 16 & Satkania & 2550 & 20.05 & 2.03 \\
\hline 17 & Chhagalnaiya & 2400 & 22.71 & 1.91 \\
\hline 18 & Banshkhali & 2300 & 12.94 & 1.83 \\
\hline 19 & Chandanaish & 2200 & 22.31 & 1.75 \\
\hline 20 & Lohagara & 2200 & 20.09 & 1.75 \\
\hline 21 & Parshuram & 1800 & 27.03 & 1.43 \\
\hline 22 & Fulgazi & 1800 & 25.25 & 1.43 \\
\hline 23 & Noakhali & 1300 & 5.26 & 1.04 \\
\hline 24 & Ukhia & 1200 & 11.89 & 0.96 \\
\hline 25 & Feni & 1000 & 5.95 & 0.80 \\
\hline 26 & Maheshkhali & 800 & 7.72 & 0.64 \\
\hline 27 & Senbag & 600 & 5.67 & 0.48 \\
\hline 28 & Sitakunda & 450 & 4.59 & 0.36 \\
\hline 29 & CoxBazar & 250 & 2.52 & 0.20 \\
\hline 30 & Kutubdia & 150 & 4.41 & 0.12 \\
\hline 31 & Ramgati & 150 & 0.62 & 0.12 \\
\hline \multirow[t]{2}{*}{32} & Ramganj & 50 & 0.44 & 0.04 \\
\hline & Chittagong region & 125600 & 19.15 & 100.00 \\
\hline
\end{tabular}

\section{Fourth dominant cropping pattern}

Fourth dominant cropping pattern GrasspeaFallow-T. Aman has occupied 30,640 hectares representing $4.65 \%$ share of NCA in Chittagong region (Table 11). This pattern is distributed over 14 upazilas where Hatiya ranked in top position. This upazila has 8,000 ha area Grasspea-Fallow-T. Aman which is only $14.42 \%$ of upazila NCA. Companiganj upazila ranks in second position with 7,700 ha area for this pattern, however, this upazila has allotted the biggest share $(34.15 \%)$ of its NCA. Grasspea is a relatively stress-tolerant pulse crop. So, it is extensively cultivated during pre-monsoon in the dry land (FAO, 1988).
Fifth dominant cropping pattern

Fifth dominant cropping pattern FallowAus-T. Aman had been covering 27,140 hectares representing $4.14 \%$ share of NCA in Chittagong region (Table 12). This pattern is distributed over 20 upazilas where Hatiya ranked in top position. This upazila had 8,000 ha area for Fallow-Aus-T. Aman pattern which is only $14.42 \%$ of upazila NCA. Sitakunda upazila had the $4^{\text {th }}$ largest area 2,800 ha for this cropping, however, this upazila had allotted the biggest share $(28.57 \%)$ of its NCA. Scarcity of irrigation water compelled the farmers to shift their rice season. They left Boro and selected rainfed Aus (FAO, 1988). In this situation, some stress- 
Table 10. Distribution of the $3^{\text {rd }}$ dominant Boro-F-F cropping pattern in Chittagong region, 2014-15.

\begin{tabular}{llrrr}
\hline & Upazila & Area (ha) & \% of upazila NCA & \% of the pattern in region \\
\hline 01 & Begumganj & 15000 & 91.35 & 30.79 \\
02 & Sonaimuri & 10100 & 93.78 & 20.73 \\
03 & Chatkhil & 7800 & 94.78 & 16.01 \\
04 & Noakhali & 5200 & 21.05 & 10.68 \\
05 & Ramganj & 3900 & 34.51 & 8.01 \\
06 & Kabirhat & 3700 & 31.17 & 7.60 \\
07 & Senbag & 1200 & 11.34 & 2.46 \\
08 & Chakaria & 700 & 3.25 & 1.43 \\
10 & Raipur & 400 & 4.74 & 0.82 \\
11 & Parshuram & 300 & 1.81 & 0.06 \\
12 & Maheshkhali & 250 & 3.75 & 0.05 \\
\hline \multicolumn{7}{l}{ Chittagong region } & 160 & 7.54 & 0.03 \\
\hline
\end{tabular}

Table 11. Distribution of the $4^{\text {th }}$ dominant Grasspea-Fallow-T. Aman cropping pattern in Chittagong region, $2014-15$.

\begin{tabular}{|c|c|c|c|c|}
\hline & Upazila & Area (ha) & $\%$ of upazila NCA & $\%$ of the pattern in region \\
\hline 01 & Hatiya & 8000 & 14.42 & 26.11 \\
\hline 02 & Companiganj & 7700 & 34.15 & 25.13 \\
\hline 03 & Subarnachar & 5700 & 15.01 & 18.60 \\
\hline 04 & Sonagazi & 5000 & 24.37 & 16.32 \\
\hline 05 & Kabirhat & 1600 & 13.48 & 5.22 \\
\hline 06 & Mirsharai & 1100 & 4.75 & 3.59 \\
\hline 07 & Feni & 900 & 5.36 & 2.94 \\
\hline 08 & Noakhali & 500 & 2.02 & 1.63 \\
\hline 09 & Dagonbhuiyan & 100 & 0.98 & 0.33 \\
\hline 10 & Anwara & 10 & 0.12 & 0.03 \\
\hline 11 & Patiya & 10 & 0.07 & 0.03 \\
\hline 12 & Rauzan & 10 & 0.08 & 0.03 \\
\hline 13 & Senbag & 10 & 0.10 & 0.03 \\
\hline & Chittagong region & 30640 & 4.67 & 100.00 \\
\hline
\end{tabular}

Table 12. Distribution of the $5^{\text {th }}$ dominant Fallow-Aus-T. Aman cropping pattern in Chittagong region, $2014-15$.

\begin{tabular}{|c|c|c|c|c|}
\hline & Upazila & Area (ha) & $\%$ of upazila NCA & $\%$ of the pattern in region \\
\hline 01 & Hatiya & 8000 & 14.42 & 29.48 \\
\hline 02 & Sonagazi & 3800 & 18.52 & 14.00 \\
\hline 03 & Sandwip & 2900 & 11.96 & 10.69 \\
\hline 04 & Sitakunda & 2800 & 28.57 & 10.32 \\
\hline 05 & Noakhali & 2800 & 11.34 & 10.32 \\
\hline 06 & Banshkahli & 2000 & 11.25 & 7.37 \\
\hline 07 & Ramganj & 1200 & 10.62 & 4.42 \\
\hline 08 & Kabirhat & 700 & 5.90 & 2.58 \\
\hline 09 & Senbag & 600 & 5.67 & 2.21 \\
\hline 10 & Fatikchhari & 400 & 1.81 & 1.47 \\
\hline 11 & Satkania & 350 & 2.75 & 1.29 \\
\hline 12 & Anwara & 300 & 3.55 & 1.11 \\
\hline 13 & Kutubdia & 250 & 7.35 & 0.92 \\
\hline 14 & Chandanaish & 200 & 2.03 & 0.74 \\
\hline 15 & Chhagalnaiya & 200 & 1.90 & 0.74 \\
\hline 16 & Dagonbhuiyan & 200 & 1.96 & 0.74 \\
\hline 17 & Mirsharai & 150 & 0.65 & 0.55 \\
\hline 18 & Patia & 150 & 1.11 & 0.55 \\
\hline 19 & Companiganj & 100 & 0.44 & 0.37 \\
\hline 20 & Hathazari & 40 & 0.41 & 0.15 \\
\hline & Chittagong region & 27140 & 4.14 & 100.0 \\
\hline
\end{tabular}


tolerant Rabi crops like grasspea, felon, cowpea, sesame etc may undergo for trial to intensify the land-use of the aforesaid system.

\section{Crop diversity and cropping intensity}

Higher number of available crops under cultivation in an area dictates its higher diversity. Number of cropping patterns is also a gross indicator of crop diversity. A total of
93 cropping patterns were identified in the whole area of Chittagong region under this investigation. The highest number of cropping patterns was identified 28 in Naokhali sadar upazila and that was 26 in Companiganj and Kabirhat; and 25 in Mirsharai (Table 13). The lowest number of cropping patterns was identified four in Begumganj followed by seven in Chatkhil and Fulgazi both. The higher

Table 13. Crop diversity and cropping intensity in Chittagong region, 2014-15.

\begin{tabular}{|c|c|c|c|c|c|c|}
\hline & Upazila & $\begin{array}{c}\text { No. of identified } \\
\text { pattern }\end{array}$ & No. of crop & $\begin{array}{l}\text { Diversity index for } \\
\text { cropping pattern }\end{array}$ & $\begin{array}{l}\text { Crop diversity } \\
\text { index (CDI) }\end{array}$ & C.I. (\%) \\
\hline 01 & Anwara & 20 & 13 & 0.752 & 0.877 & 212 \\
\hline 02 & Banshkhali & 15 & 11 & 0.889 & 0.945 & 205 \\
\hline 03 & Boalkhali & 12 & 10 & 0.724 & 0.853 & 160 \\
\hline 04 & Chandanaish & 19 & 14 & 0.884 & 0.950 & 213 \\
\hline 05 & Fatikchhari & 24 & 20 & 0.609 & 0.767 & 144 \\
\hline 06 & Hathazari & 17 & 15 & 0.697 & 0.806 & 163 \\
\hline 07 & Lohagara & 12 & 9 & 0.810 & 0.896 & 181 \\
\hline 08 & Mirsharai & 25 & 18 & 0.739 & 0.846 & 190 \\
\hline 09 & Patiya & 13 & 10 & 0.716 & 0.868 & 171 \\
\hline 10 & Rngunia & 17 & 16 & 0.637 & 0.793 & 172 \\
\hline 11 & Rauzan & 18 & 15 & 0.692 & 0.826 & 171 \\
\hline 12 & Sandwip & 18 & 17 & 0.723 & 0.890 & 170 \\
\hline 13 & Satkania & 16 & 11 & 0.782 & 0.879 & 182 \\
\hline 14 & Sitakunda & 18 & 16 & 0.843 & 0.932 & 215 \\
\hline 15 & Chakaria & 17 & 15 & 0.684 & 0.863 & 231 \\
\hline 16 & CoxBazar & 18 & 14 & 0.509 & 0.733 & 192 \\
\hline 17 & Kutubdia & 9 & 7 & 0.413 & 0.776 & 279 \\
\hline 18 & Maheskhali & 13 & 13 & 0.521 & 0.687 & 174 \\
\hline 19 & Pekua & 11 & 12 & 0.598 & 0.852 & 240 \\
\hline 20 & Ramu & 16 & 17 & 0.546 & 0.758 & 193 \\
\hline 21 & Teknaf & 11 & 11 & 0.484 & 0.673 & 127 \\
\hline 22 & Ukhia & 10 & 8 & 0.586 & 0.746 & 178 \\
\hline 23 & Chhagalnaiya & 16 & 15 & 0.639 & 0.781 & 175 \\
\hline 24 & Dagonbhuiyan & 17 & 18 & 0.652 & 0.799 & 174 \\
\hline 25 & Feni & 11 & 11 & 0.647 & 0.827 & 202 \\
\hline 26 & Fulgazi & 7 & 7 & 0.551 & 0.726 & 174 \\
\hline 27 & Parshuram & 12 & 11 & 0.611 & 0.760 & 170 \\
\hline 28 & Sonagazi & 18 & 12 & 0.819 & 0.916 & 185 \\
\hline 29 & Kamalnagar & 10 & 9 & 0.655 & 0.872 & 283 \\
\hline 30 & Lakshmipur & 17 & 14 & 0.691 & 0.859 & 209 \\
\hline 31 & Ramganj & 17 & 14 & 0.786 & 0.892 & 169 \\
\hline 32 & Ramgati & 16 & 15 & 0.640 & 0.864 & 281 \\
\hline 33 & Raipur & 12 & 10 & 0.784 & 0.908 & 220 \\
\hline 34 & Begumganj & 4 & 5 & 0.151 & 0.269 & 108 \\
\hline 35 & Chatkhil & 7 & 7 & 0.084 & 0.135 & 103 \\
\hline 36 & Companiganj & 26 & 23 & 0.737 & 0.857 & 165 \\
\hline 37 & Hatiya & 15 & 13 & 0.872 & 0.938 & 224 \\
\hline 38 & Kabirhat & 26 & 23 & 0.776 & 0.867 & 139 \\
\hline 39 & Noakhali & 28 & 18 & 0.886 & 0.944 & 192 \\
\hline 40 & Senbag & 13 & 12 & 0.523 & 0.738 & 189 \\
\hline 41 & Sonaimuri & 8 & 9 & 0.091 & 0.155 & 104 \\
\hline \multirow[t]{2}{*}{42} & Subarnachar & 23 & 18 & 0.833 & 0.926 & 183 \\
\hline & Chittagong region & 93 & 31 & 0.893 & 0.952 & 191 \\
\hline
\end{tabular}


number of cropping patterns is generally related to higher level of crop diversity indices. The upazilas having lower number of cropping patterns were related to either salinity or water logging or both. Begumganj and Chatkhil face both thelimitations. The lowest diversity index for cropping pattern was recorded 0.084 in Chatkhil followed by 0.151 in Begumganj. In a study Shahidullah et al. (2006) also found lowest values for all the diversity and intensity parameters in salt affected areas of greater Noakhali. The highest value of diversity index for cropping pattern was found 0.889 in Banshkhali upazila of Chittagong district that was followed by 0.886 in Noakhali sadar upazila. The lowest CDI was reported 0.135 in Chatkhil followed by 0.269 in Begumganj. The highest value of CDI was observed 0.945 in Banshkhali followed by 0.944 in Noakhali sadar upazila. The range of cropping intensity values was recorded $103-283 \%$. The maximum value was for Kamalnagar upazila of Lakshmipur district and minimum for Chatkhil upazila of Noakhali district. As a whole the CDI of Chittagong region was calculated 0.952 and the average cropping intensity at regional level was $191 \%$. In a simultaneous study, the investigators identified 316 cropping patterns for whole Bangladesh; where the CDI value was 0.952 at national level and the national average of cropping intensity was $200 \%$ (Nasim et al., 2017). Diversified cropping pattern might enable the farmers compulsion of extracting the maximum possible use of land in the flood free period (Mandal and Bezbaruah, 2013). Singh and Sidhu (2006) reported that a number of crops like sun hemp, cluster beans and sorghum had almost disappeared and there is reduced varietal diversification in rice and wheat. Crop diversification index of wheat-rice system decreased from 0.75 in 1975-76 to 0.58 in 2006-07 in Punjab though diversification forces pests to continuously relocate and re-colonize their preferred host plants from year to year (Tscharntke et al., 2005, 2007).

\section{COCLUSION}

The cropping intensity of the Chittagong region was little bit lower than the national average.
Boro-Fallow-T. Aman, Single T. Aman, single Boro, Grasspea-Fallow-T. Aman, FallowAus-T. Aman were the dominant cropping patterns in the region. Exclusive rice area is about 23 folds of exclusive non-rice area. The non-rice based cropping patterns were either few or area under those cropping patters were much lower which are challenges to food and nutritional security for the people of the Chittagong region. Based on the findings of the study, the following recommendations can be made.

- Initiative has to be taken to increase productivity of exclusive rice based cropping pattern as rice is the synonym of the primary food security. The high yielding varieties of rice along with recommended crop management packages to be adopted.

- The upazilas having unique or exceptional cropping patterns with large area coverage might be studied in-depth to extrapolate to similar environments.

- Effort might be invested so that a portion of single T. Aman area could be brought under Felon-T. Aman and/or Grasspea-T. Aman cropping systems.

- In the single Boro area suitable vegetables might be grown on floating bed system in wet season.

\section{REFERENCES}

Agrawal, D J and A H Kassam. 1976. The importance of multiple cropping in increasing world food supplies. A special publication No. 27, American Society of Agronomy, Madison, Wisconsin. pp. 2-3.

FAO, 1988. Land Resources Appraisal of Bangladesh for Agricultural Development- Report 2: Agroecological regions of Bangladesh. Food and Agriculture Organization of the United Nations, Rome, Italy, $570 \mathrm{p}$.

Gadge, S S. 2003. Influence of changes in cropping pattern on farmers' economic status. Indian J. Ext. Edu. 39(1\&2): 99-101.

Kshirsagar, K G, S Pandey and M R Bellon. 1997. Farmers' perception, varietal characteristics and technology adoption: the case of rainfed village in eastern India. Discussion paper 5/97. Social Sciences Division, International Rice Research Institute. Los Baňos, Laguna, Philippines. 
Mandal, R and M P Bezbaruah. 2013. Diversification of cropping pattern: its determinants and role in flood affected agriculture of Assam Plains. Indian J. Agric. Econ. 68(2): 169-181.

Nasim, M, S M Shahidullah, A Saha, M A Muttaleb, T L Aditya, M A Ali and M S Kabir. 2017. Distribution of Crops and Cropping Patterns in Bangladesh. Bangladesh Rice J. 21(2): 1-55.

Neena, D. 1998. Interstate variation in cropping pattern in India. Indian J. Regi. Sci. 30(2): 57-69.

Rashid, M H, A H Khan and M MAlam. 2005. Cropping systems dynamics in greater Khustia. J. Bangladesh Agril. Univ. 3(2):213-238.

Shahidullah, S M, M S A Talukder, M S Kabir, A H Khan and N E Elahi. 2006. Cropping patterns in the South
East Coastal Region of Bangladesh. J. Agric. Rural Dev. 4(1\&2): 53-60.

Shriar, A J. 2000. Agricultural intensity and its measurement in frontier regions.Agroforestry Systems.49(3): 301-318.

Singh, J. and R S Sidhu. 2006. Accounting for impact of environmental degradation in agriculture of Indian Punjab. Agric. Economics Res. Rev. 19: 37-48.

Tscharntke, T, R Bommarco, Y Clough, T O Crist, D Klein, T A Rand, J M Tylianakis, S vanNouhuys, and S Vidal. 2007. Conservation biological control and enemy diversity on a landscape scale. Biol. Control. 43: 294-309.

Tscharntke, T., A M Klein, A Kruess, I S Dewenter, and C Thies. 2005. Landscape perspectives on agricultural intensification and biodiversity-ecosystem service management. Ecol. Lett. 8: 857-874.

Appendix 1. List of cropping patterns in Chittagong region, 2014-15.

\begin{tabular}{|c|c|c|c|c|c|}
\hline & Cropping pattern & Area(ha) & & Cropping pattern & Area (ha) \\
\hline 01 & Boro-Fallow-T. Aman & 150280 & 36 & Boro-Vegetab-T. Aman & 1900 \\
\hline 02 & Fallow-Fallow-T. Aman & 125600 & 37 & Vegetab-Boro-Fallow & 1800 \\
\hline 03 & Boro-Fallow-Fallow & 48710 & 38 & Potato-Boro-T. Aman & 1650 \\
\hline 04 & Grasspea-Fallow-T. Aman & 30640 & 39 & Fallow-Vegetab-T. Aman & 1480 \\
\hline 05 & Fallow-Aus-T. Aman & 27140 & 40 & Fallow-Aus-Fallow & 1000 \\
\hline 06 & Soybean-Aus-T. Aman & 22600 & 41 & Boro-Aus-Fallow & 900 \\
\hline 07 & Soybean-Jute-T. Aman & 19400 & 42 & Chilli-Aus-Fallow & 770 \\
\hline 08 & Soybean-Fallow-T. Aman & 18670 & 43 & Pea-Fallow-T. Aman & 730 \\
\hline 09 & Vegetab-Fallow-T. Aman & 17715 & 44 & Soybean-Aus-Fallow & 700 \\
\hline 10 & Grasspea-Aus-T. Aman & 16740 & 45 & Vegetab-Groundnut-T. Aman & 700 \\
\hline 11 & Boro-Aus-T. Aman & 16070 & 46 & Mustard-Boro-T. Aman & 660 \\
\hline 12 & Felon-Fallow-T. Aman & 14630 & 47 & Tobacco-Sesbania & 600 \\
\hline 13 & Chilli-Fallow-T. Aman & 9450 & 48 & Maize-Fallow-T. Aman & 595 \\
\hline 14 & Groundnut-Fallow-T. Aman & 8630 & 49 & Garlic-Fallow-T. Aman & 535 \\
\hline 15 & Vegetab-Vegetab-T. Aman & 8505 & 50 & Lentil-Aus-T. Aman & 500 \\
\hline 16 & Groundnut- Aus-T. Aman & 8350 & 51 & Coriander-Fallow-T. Aman & 475 \\
\hline 17 & Vegetab-Boro-T. Aman & 8150 & 52 & Groundnut-Fallow-Fallow & 440 \\
\hline 18 & Mungbean-Aus-T. Aman & 7040 & 53 & Felon-Aus-Fallow & 420 \\
\hline 19 & Vegetab-Aus-T. Aman & 5500 & 54 & Tobacco-Fallow-T. Aman & 400 \\
\hline 20 & Vegetab-Vegetab-Vegetab & 5235 & 55 & Muskmelon-Fallow-T. Aman & 345 \\
\hline 21 & Felon-Aus-T. Aman & 5045 & 56 & Mustard-Aus-T. Aman & 345 \\
\hline 22 & Potato-Fallow-T. Aman & 4555 & 57 & Chilli-Fallow-Fallow & 300 \\
\hline 23 & S.Potato-Fallow-T. Aman & 4390 & 58 & S.Potato-Fallow-Fallow & 300 \\
\hline 24 & Mungbean-Fallow-T. Aman & 4335 & 59 & Mustard-Boro-Aus-T. Aman & 270 \\
\hline 25 & Soybean-B.Aman & 4300 & 60 & Felon-Fallow-Fallow & 260 \\
\hline 26 & Vegetab-Fallow-Fallow & 3920 & 61 & Coriander-Fallow-Fallow & 250 \\
\hline 27 & Vegetab-Aus-Fallow & 2900 & 62 & Grasspea-B.Aman & 250 \\
\hline 28 & Boro-B.Aman & 2850 & 63 & Vegetab-Boro-Aus-T. Aman & 250 \\
\hline 29 & W.Melon-Fallow-T. Aman & 2790 & 64 & Onion-Fallow-T. Aman & 245 \\
\hline 30 & Vegetab-Vegetab-Fallow & 2560 & 65 & Potato-Sesame-T. Aman & 200 \\
\hline 31 & Chilli-Aus-T. Aman & 2450 & 66 & W.Melon-Fallow-Fallow & 195 \\
\hline 32 & Lentil-Fallow-T. Aman & 2440 & 67 & Sesame-Fallow-T. Aman & 175 \\
\hline 33 & Mustard-Fallow-T. Aman & 2370 & 68 & Potato-Aus-T. Aman & 165 \\
\hline 34 & S.Potato-Aus-T. Aman & 2150 & 69 & Chilli-Vegetab-Fallow & 130 \\
\hline 35 & Soybean-Fallow-Fallow & 2000 & $70-93$ & Other 24 patterns (Table 7) & 910 \\
\hline
\end{tabular}

